\title{
EFISIENSI TEKNIS USAHATANI JAGUNG MANIS DI DESA GUNUNG MALANG KECAMATAN TENJOLAYA KABUPATEN BOGOR: PENDEKATAN DATA ENVELOPMENT ANALYSIS
}

\author{
Melissa Amandasari' ${ }^{1)}$ Rita Nurmalina ${ }^{2)}$ dan Amzul Rifin ${ }^{3)}$ \\ ${ }^{1,2,3)}$ Departemen Agribisnis, Fakultas Ekonomi dan Manajemen, Institut Pertanian Bogor \\ ${ }^{1)}$ mel2691@yahoo.com
}

\begin{abstract}
Efficiency can be used as a measurement for decision making. Technical efficiency is one of them. The objectives of the research are (1) to analyze farming techniques and input usage, (2) to measure the technical efficiency and (3) to identify factors affecting technical efficiency of maize farm in Gunung Malang, Tenjolaya, Bogor Regency. Data Envelopment Analysis (DEA) approach and Tobit Regression are used to analyze. The result shows that farmers in Gunung Malang are inefficient in the use of production inputs. Farmers need to decrease manure usage, TSP fertilizer, and outside labor for technical efficiency. Factors that are affecting the technical efficiency are formal education level, number of household member and farmer association membership.
\end{abstract}

Keyword(s): DEA, sweet corn, technical efficiency, tobit regression

\begin{abstract}
ABSTRAK
Efisiensi dapat dijadikan sebagai alat ukur untuk pemilihan pengambilan keputusan. Salah satu bentuk efisiensi dalam usahatani adalah efisiensi teknis. Tujuan penelitian ini yaitu (1) untuk mengkaji keragaan usahatani dan penggunaan input produksi jagung manis, (2) mengukur efisiensi teknis usahatani jagung manis dan (3) mengidentifikasi faktor-faktor yang mempengaruhi efisiensi teknis usahatani jagung manis di Desa Gunung Malang, Kecamatan Tenjolaya, Kabupaten Bogor. Pendekatan Data Envelopment Analysis (DEA) dan Regresi Tobit digunakan untuk menganalisis data. Hasil penelitian menunjukkan bahwa petani jagung manis di Desa Gunung Malang tidak efisien dalam penggunaan input-input produksinya. Petani dapat mengurangi penggunaan pupuk kandang, pupuk TSP, dan tenaga kerja luar keluarga agar usahatani jagung manis yang dilakukan efisien secara teknis. Faktor-faktor yang mempengaruhi efisiensi teknis usahatani jagung manis di Desa Gunung Malang yaitu tingkat pendidikan formal, jumlah tanggungan di dalam rumah tangga petani, dan keanggotaan dalam kelompok tani.
\end{abstract}

Kata Kunci: Data Envelopment Analysis, efisiensi teknis, jagung manis, regresi tobit

\section{PENDAHULUAN}

Jagung merupakan bahan pangan penting karena merupakan sumber karbohidrat kedua setelah padi, sehingga sebagai salah satu sumber bahan pangan, jagung telah menjadi komoditas utama setelah padi. Industri yang banyak menggunakan jagung sebagai bahan baku yaitu industri pakan ternak dan industri non-pangan, serta industri makanan dan minuman. Peranan jagung yang dapat digunakan dalam berbagai industri 
tersebut membuat budidaya jagung memiliki prospek yang sangat baik (Tim Karya Tani Mandiri, 2010).

Selama periode 2005-2009, kebutuhan jagung untuk bahan industri pakan ternak, makanan, dan minuman terus mengalami peningkatan setiap tahunnya. Kebutuhan jagung nasional dalam kurun waktu lima tahun tersebut menunjukkan peningkatan dari 12,26 juta ton pipilan kering (2005) menjadi 17,66 juta ton pipilan kering (2009), dengan laju peningkatan sebesar 11,38 persen per tahun. Proyeksi kebutuhan jagung nasional pada tahun 2013 sekitar 23.61 juta ton dan pada tahun 2014 dibutuhkan sekitar 26.29 juta ton bahan baku jagung (Departemen Pertanian, 2009).

Produksi, luas panen, dan produktivitas jagung di Indonesia pada tahun 2010 sampai 2012 cenderung mengalami fluktuasi. Meskipun pada tahun 2010 produksi jagung di Indonesia mengalami peningkatan dibandingkan dengan tahun 2009 yang memiliki jumlah produksi sebesar 17.629.748 ton, jumlah produksi tersebut belum mampu mengimbangi jumlah konsumsi jagung di Indonesia. Pada tahun 2011, konsumsi jagung di Indonesia mencapai 18.800 .000 ton, sedangkan jumlah produksi jagung yang dihasilkan hanya 17.643.250 ton (Badan Pusat Statistik, 2012).

Salah satu sentra produksi jagung di Indonesia yaitu Jawa Barat. Produksi jagung di Jawa Barat terus mengalami peningkatan seiring dengan adanya program pemerintah mengenai perluasan areal penanaman jagung di Indonesia, terutama di Jawa Barat. Upaya pemerintah untuk meningkatkan produksi jagung pada tahun 2011 yaitu melalui penciptaan dan penelitian varietas benih unggul, penyelenggaraan Sekolah Lapangan Pengelolaan Tanaman Terpadu (SLPTT), Bantuan Langsung Benih Unggul (BLBU), pemberian bantuan benih dari cadangan benih nasional (CBN), Gerakan Peningkatan Produksi Pangan Berbasis Korporasi (GP3K), dan pelatihan (Kementerian Pertanian, 2012).

Salah satu sentra produksi jagung di Provinsi Jawa Barat terdapat di Kabupaten Bogor dengan luas panen sebesar 750 hektar dan produksi sebesar 2.956 ton. Meskipun sebagai salah satu sentra jagung di Jawa Barat, Kabupaten Bogor memiliki jumlah produksi yang sangat rendah apabila dibandingkan dengan Kabupaten Garut yang merupakan sentra produksi jagung di Provinsi Jawa Barat. Oleh karena itu, pengembangan potensi jagung di Kabupaten Bogor perlu dilakukan untuk dapat meningkatkan produksi jagung nasional (Dinas Pertanian Tanaman Pangan Provinsi Jawa Barat, 2012).

Tipe jagung yang dikembangkan di daerah Kabupaten Bogor pada umumnya adalah jagung manis. Tanaman jagung manis sudah banyak dikenal di daerah Jawa Barat daripada di daerah lainnya. Hal ini ditunjukkan dengan tingginya permintaan benih jagung manis yang mencapai 50 ton pada tahun 2006 untuk provinsi Jawa Barat, sedangkan untuk provinsi Jawa Timur hanya 20 ton $^{1}$.

\footnotetext{
${ }^{1}$ http://www.agrina-online.com/show_article.php?rid=10\&aid=709. [07 Mei 2013] 
Kecamatan Tenjolaya merupakan salah satu daerah penghasil jagung manis di Kabupaten Bogor. Peningkatan luas panen dan tingkat produksi jagung manis terbesar di Kabupaten Bogor pada tahun 2011 terjadi di Kecamatan Tenjolaya (Badan Pusat Statistik Kabupaten Bogor, 2012), dimana Desa Gunung Malang merupakan sentra produksi jagung manis di Kecamatan Tenjolaya.

Produktivitas rata-rata yang dihasilkan oleh petani jagung manis di Desa Gunung Malang baru mencapai 6,17 ton per hektar, jauh lebih rendah jika dibandingkan dengan produktivitas nasional yaitu sebesar 12-14 ton per hektar. Selain itu, terdapat variasi produktivitas per hektar diantara petani jagung manis di Desa Gunung Malang, yang diduga karena adanya variasi pada penggunaan faktor-faktor produksi di dalam melakukan usahatani jagung manis. Hal ini salah satunya dapat terlihat pada rata-rata penggunaan input produksi dari petani responden seperti pupuk kimia dan pupuk kandang yang masih belum sesuai dengan penggunaan pupuk yang dianjurkan (Amandasari, 2013).

Bakhsh et al. (2006) menyatakan bahwa salah satu cara untuk meningkatkan produksi, yaitu dengan menggunakan sumberdaya yang tersedia secara lebih efisien. Hal ini juga didukung oleh penelitian yang menyatakan bahwa peningkatan efisiensi teknis dapat meningkatkan produksi (Bakhsh et al. 2006) dan menekan biaya usahatani sehingga dapat meningkatkan pendapatan petani (Ogundari dan Ojo, 2007).

Upaya peningkatan efisiensi dalam suatu usahatani salah satunya sangat dipengaruhi oleh faktor-faktor sosialekonomi dari petani. Faktor-faktor internal berkaitan sangat erat dengan kapabilitas manajerial petani dalam melaksanakan praktik usahatani (Sumaryanto dan Siregar, 2003). Variabel-variabel seperti pendidikan formal, keterlibatan pada kelembagaan pertanian, pengalaman berusahatani, jumlah tanggungan dalam keluarga, dan umur petani merupakan beberapa indikator penting yang dapat dijadikan sebagai faktor-faktor penentu tingkat efisiensi usahatani.

Selain faktor-faktor sosial-ekonomi dari petani, upaya peningkatan efisiensi dalam suatu usahatani sangat dipengaruhi oleh teknik budidaya yang dilakukan dan faktor-faktor produksi yang digunakan dalam melakukan kegiatan usahatani, seperti benih, pupuk, pestisida, dan tenaga kerja.

Oleh karena itu perbaikan dalam penggunaan faktor-faktor produksi di dalam melakukan usahatani jagung manis perlu dilakukan agar produktivitas jagung manis di Desa Gunung Malang dapat meningkat. Berdasarkan uraian tersebut, maka tujuan penelitian ini antara lain (1) mengkaji keragaan usahatani dan penggunaan input produksi jagung manis, (2) mengukur efisiensi teknis usahatani jagung manis, dan (3) mengidentifikasi faktor-faktor yang mempengaruhi efisiensi teknis usahatani jagung manis di Desa Gunung Malang.

\section{METODE PENELITIAN}

\section{Metode Pengumpulan Data}

Penelitian dilakukan di Desa Gunung Malang, Kecamatan Tenjolaya, Kabupaten Bogor, Provinsi Jawa Barat. 
Pemilihan lokasi penelitian ditentukan secara sengaja (purposive) dengan pertimbangan bahwa Kabupaten Bogor merupakan salah satu sentra produksi jagung di Jawa Barat dan Desa Gunung Malang merupakan sentra produksi jagung manis di Kabupaten Bogor dan terdapat cukup banyak petani yang melakukan usahatani jagung manis secara monokultur. Waktu penelitian dilakukan pada bulan Februari 2013-Mei 2014.

Penentuan responden dalam penelitian ini menggunakan metode survey. Jumlah petani yang digunakan sebagai responden adalah sebanyak 31 orang petani yang masih aktif melakukan kegiatan usahatani jagung manis di Desa Gunung Malang. Responden sebanyak 31 orang merupakan keseluruhan petani yang hanya melakukan usahatani jagung manis secara monokultur di Desa Gunung Malang.

\section{Analisis Efisiensi Teknis}

Model yang digunakan dalam penelitian ini adalah Model DEA. Model ini digunakan untuk menganalisis efisiensi relatif usahatani jagung manis. Nilai efisiensi sama dengan satu menunjukkan bahwa usahatani jagung manis relatif efisien, sedangkan nilai efisiensi kurang dari satu menunjukkan bahwa usahatani jagung manis relatif tidak efisien (Farrell, 1957).

Model DEA memiliki beberapa keunggulan dibandingkan dengan model lainnya, yaitu model DEA dapat mengukur banyak variabel input dan output, tidak memerlukan asumsi hubungan fungsional antara variabel yang diukur (input dan output), DMU dibandingkan secara langsung antara satu sama lain, dan variabel input dan output dapat memiliki satuan pengukuran yang berbeda. Namun pengujian hipotesis secara statistik atas hasil DEA sulit dilakukan karena DEA merupakan pengukuran non parametrik.

Model DEA yang digunakan adalah model yang berorientasi input, karena petani lebih memiliki kontrol atas input yang digunakan dibandingkan dengan output yang dihasilkan. Penelitian ini juga menggunakan pendekatan Variable Return to Scale karena usahatani jagung manis di lokasi penelitian hampir tidak mungkin mencapai skala optimal. Jadi, penggunaan model DEA VRS dianggap lebih tepat daripada penggunaan model DEA CRS untuk penelitian ini.

Secara matematis, perhitungan efisiensi teknis menggunakan model variable return to scale dinyatakan sebagai berikut:

$$
\begin{gathered}
\operatorname{Min}_{\theta, \lambda} \theta, \\
\text { st }-q_{i}+Q \lambda \geq 0, \\
\theta x_{i}-X \lambda \geq 0, \\
\mathrm{I}^{\prime} \lambda=1 \\
\lambda \geq 0
\end{gathered}
$$

Dimana I1 adalah vektor $I x I, \theta$ adalah pengurangan proporsional input yang mungkin untuk DMU ke-i dengan asumsi output konstan, dan $\lambda$ adalah bobot dari DMU ke-j.

Model yang digunakan dalam penelitian ini terdiri dari variabel input dan output. Variabel input yang digunakan yaitu benih, pupuk urea, pupuk TSP, pupuk kandang, furadan, 
tenaga kerja dalam keluarga, dan tenaga kerja luar keluarga. Sementara itu, variabel output yang digunakan dalam penelitian ini yaitu produksi dan produktivitas jagung manis. Untuk menghitung nilai efisiensi dari usahatani jagung manis yang diteliti, maka penelitian ini menggunakan program komputer, yaitu DEAP versi 2.1.

\section{Model Regresi Tobit}

Skor DEA memiliki nilai efisiensi yang bervariasi antara 0,00 sampai 1,00. Jenis lain dari model regresi seperti multiple linear, regresi logistik, bahkan metode ordinary least square hanya dapat diterapkan jika nilai efisiensi tidak mengasumsikan salah satu dari batas atas dan bawah atau dari keduanya, sehingga akan memberikan perkiraan yang bias. Oleh karena itu dalam penelitian ini digunakan model regresi Tobit untuk mengidentifikasi sumber-sumber efisiensi karena variabel dependent pada penelitian ini diasumsikan 0 sebagai batas bawah dan 1 sebagai batas atas (Maddala, 1999).

Indeks efisinsi teknis yang dihasilkan dari analisis DEA antara 0 sampai dengan 1 akan digunakan dalam model regresi Tobit untuk menjelaskan hubungan antara tingkat efisiensi teknis dengan karakteristik petani. Berdasarkan berbagai studi terdahulu, terdapat beberapa faktor yang diduga berpengaruh terhadap tingkat efisiensi teknis petani jagung manis di lokasi penelitian. Faktor potensial yang diperkirakan mempengaruhi kinerja efisiensi teknis (TE) jagung manis yaitu usia (AGE), pendidikan (EDU), pengalaman petani dalam usaha- tani jagung manis (EXP), jumlah tanggungan di dalam rumah tangga petani (FAM), dan keanggotaan dalam kelompoktani (ASSOC). Model Tobit yang digunakan adalah:

$$
\begin{gathered}
\mathrm{TE}=\beta_{0}+\beta_{1} \mathrm{AGE}+\beta_{2} \mathrm{EDU}+ \\
\beta_{3} \mathrm{EXP}+\beta_{4} \mathrm{FAM}+ \\
\beta_{5} \mathrm{ASSOC}+\varepsilon
\end{gathered}
$$

Hipotesis yang digunakan untuk model efisiensi teknis dalam penelitian ini yaitu:

1. Usia

Semakin tua usia, diduga akan berpengaruh negatif terhadap efisiensi teknis.

2. Pendidikan

Tingkat pendidikan diduga akan berpengaruh positif terhadap efisiensi teknis.

3. Pengalaman

Semakin lama pengalaman petani dalam melakukan usahatani jagung manis, diduga akan berpengaruh positif terhadap efisiensi teknis.

4. Jumlah tanggungan di dalam rumah tangga petani

Jumlah tanggungan petani diduga akan berpengaruh negatif terhadap efisiensi teknis.

5. Keanggotaan dalam kelompoktani Keanggotaan dalam kelompoktani diduga akan berpengaruh positif terhadap efisiensi teknis.

\section{HASIL DAN PEMBAHASAN}

Keragaan Usahatani Jagung Manis di Desa Gunung Malang

Penanaman jagung manis yang dilakukan oleh petani responden dilaku- 
kan secara monokultur. Pada umumnya, alasan petani melakukan budidaya jagung manis secara monokultur yaitu karena ingin mendapatkan hasil panen yang maksimal dari segi ukuran jagung, sehingga dapat memperoleh keuntungan yang cukup besar. Total kepemilikan luas lahan jagung manis dari petani responden bervariasi antara satu petani dengan petani lainnya. Luas lahan terkecil yaitu sebesar 0.1 hektar dan luas lahan terbesar mencapai 1 hektar. Umumnya petani responden di Desa Gunung Malang belum memiliki lahan yang luas dalam melakukan budidaya jagung manis, karena sebesar 74,19\% petani masih memiliki lahan dibawah 0,5 hektar.

Sebagian besar petani responden di Desa Gunung Malang menjadikan usahatani jagung manis sebagai mata pencaharian utama, dimana sebesar $61,29 \%$ petani responden menjadikan usahatani jagung manis sebagai mata pencaharian utama, sedangkan sisanya sebesar $38,71 \%$ petani responden menjadikan usahatani jagung manis sebagai mata pencaharian sampingan.

Terkait penggunaan benih, petani menggunakan benih jagung manis hibrida varietas Hawai, Golden, Talenta, dan Sweet Boy. Sebagian besar petani menggunakan benih jagung manis varietas Hawai. Varietas Hawai dipilih karena menurut petani varietas Hawai ini lebih murah dibandingkan dengan benih varietas lainnya. Selain itu varietas Hawai dianggap lebih sesuai dengan kondisi alam Desa Gunung Malang. Menurut petani, benih varietas Hawai ini memiliki daya tumbuh yang besar, lebih tahan terhadap penyakit, jarang gagal panen, pertumbuhannya cepat, dan tongkolnya besar.

Sebagian besar petani menggunakan pola tanam padi-ubi jalar-jagung manis di dalam melakukan usahatani pada musim tanam 2013 (sebanyak 26 petani dari 31 total responden atau sebesar 83,87 persen). Alasan petani untuk menanam jagung manis pada akhir tahun karena tergiur oleh tingginya permintaan jagung manis dimana pada saat pergantian tahun atau tahun baru, permintaan jagung manis lebih banyak dibandingkan pada hari-hari biasa.

Kegiatan pemasaran jagung manis di Desa Gunung Malang dianggap sangat mudah oleh petani responden meskipun pemasaran produk jagung manis masih didominasi oleh tengkulak. Banyak para pembeli terutama tengkulak yang setiap hari datang ke Desa Gunung Malang untuk membeli jagung manis serta tanaman lainnya untuk dijual ke pasar. Petani responden yang menjual hasil panennya kepada tengkulak yaitu sebanyak 19 orang atau sekitar 61,29\% dari total responden. Petani yang menjual hasil panennya sendiri merupakan petani yang memiliki kios atau akses ke pasar induk yaitu di Pasar Bogor dan Pasar Kemang Bogor, yang memiliki proporsi sebesar 38,71\% dari total responden.

Selain aktivitas pemasaran, hal lain yang perlu diperhatikan yaitu aktivitas usahatani. Aktivitas usahatani dilakukan melalui beberapa tahap, diantaranya kegiatan persiapan lahan, penanaman, pemupukan, pemeliharaan tanaman (seperti penyiangan, pembumbunan, serta pengendalian hama dan penyakit), dan pemanenan. Input produksi yang 
digunakan dalam penelitian ini yaitu benih, pupuk kimia (urea dan TSP), pupuk kandang, pestisida padat (furadan), dan tenaga kerja (dalam dan luar keluarga). Penggunaan input-input produksi tersebut cenderung bervariasi diantara masing-masing petani dan terdapat beberapa input yang penggunaannya masih belum sesuai dengan komposisi yang dianjurkan, seperti pupuk urea, pupuk TSP, pupuk kandang, dan furadan.

\section{Efisiensi Teknis Usahatani Jagung Manis}

Analisis efisiensi teknis dilakukan melalui pendekatan Data Envelopment Analysis (DEA) dengan orientasi input dan variable return to scale. Data yang digunakan dalam penelitian ini adalah data pada musim tanam 2013-2014. Variabel output yang digunakan yaitu produksi jagung manis $\left(\mathrm{Y}_{1}\right)$ dan produktivitas jagung manis $\left(\mathrm{Y}_{2}\right)$. Sedangkan variabel input yang digunakan adalah benih $\left(\mathrm{X}_{1}\right)$, pupuk urea $\left(\mathrm{X}_{2}\right)$, pupuk TSP $\left(\mathrm{X}_{3}\right)$, pupuk kandang $\left(\mathrm{X}_{4}\right)$, furadan $\left(\mathrm{X}_{5}\right)$, tenaga kerja dalam keluarga $\left(\mathrm{X}_{6}\right)$, dan tenaga kerja luar keluarga $\left(\mathrm{X}_{7}\right)$.

Berdasarkan hasil perhitungan menggunakan DEAP versi 2.1, diperoleh hasil yang menunjukkan bahwa persentase responden yang memiliki nilai efisiensi sama dengan satu sebesar 41,94 persen, sedangkan persentase responden yang memiliki nilai efisiensi kurang dari satu sebesar 58,06 persen dari total responden (untuk model DEA VRS). Nilai efisiensi teknis petani jagung manis di Desa Gunung Malang bervariasi antara 40,3 persen hingga 100 persen (Tabel 1).
Output lain yang diperoleh dari perhitungan dengan menggunakan Data Envelopment Analysis (DEA) yaitu diperolehnya keterangan yang menunjukkan kecenderungan tren pada petani di lokasi penelitian (Lampiran 1). Model DEA CRS dan VRS digunakan untuk menentukan kecenderungan tren pada petani jagung manis di lokasi penelitian tergolong pada increasing return to scale (IRS), decreasing return to scale (DRS), atau constant return to scale (CRS). Petani yang berada pada posisi meningkatkan skala pengembaliannya (increasing return to scale) berada di posisi dimana peningkatan output lebih besar daripada peningkatan input. Sedangkan petani yang berada pada posisi penurunan skala pengembaliannya (decreasing return to scale) berada di posisi dimana peningkatan output lebih kecil daripada peningkatan input produksi.

Petani responden yang tergolong pada increasing return to scale (IRS) sebanyak 18 orang (58,06 persen), sebanyak 3 orang $(9,68$ persen) tergolong pada decreasing return to scale (DRS), dan sebanyak 10 orang (32,26 persen) tergolong pada constant return to scale (CRS). Berdasarkan hal tersebut, terlihat bahwa rata-rata petani responden di Desa Gunung Malang berada pada posisi dimana peningkatan output lebih besar daripada peningkatan input (increasing return to scale). Hasil yang diperoleh pada penelitian ini serupa dengan hasil pada penelitian yang dilakukan oleh Dao dan Lewis (2008) dan Abatania et al. (2012), dimana rata-rata petani yang menanam tanaman tahunan (sebesar 
Tabel 1. Nilai Rata-rata dari Constant Return to Scale Technical Efficiency (CRSTE), Variable Return to Scale Technical Efficiency (VRSTE), dan Scale Efficiency (SE) Petani Responden

\begin{tabular}{lccc}
\hline \multicolumn{1}{c}{ Keterangan } & CRSTE & VRSTE & SE \\
\hline Mean & 0,763 & 0,870 & 0,897 \\
Maksimum & 1,000 & 1,000 & 1,000 \\
Minimum & 0,402 & 0,403 & 0,638 \\
Jumlah nilai efisiensi sama dengan satu & 10 & 13 & 10 \\
Jumlah nilai efisiensi kurang dari satu & 21 & 18 & 21 \\
\hline
\end{tabular}

77,27 persen) dan petani yang menanam tanaman pangan (sebesar 46,56 persen) berada pada kondisi increasing return to scale (peningkatan output lebih besar daripada peningkatan input). Sedangkan pada penelitian yang dilakukan oleh Ogunniyi (2012) ditemukan bahwa mayoritas petani jagung di Nigeria beroperasi pada kondisi decreasing return to scale (peningkatan output lebih kecil daripada peningkatan input produksi).

Salah satu keunggulan dari metode analisis Data Envelopment Analysis (DEA) yaitu dalam hal melihat perbandingan diantara DMU yang diteliti. Dalam DEA, responden yang tidak efisien dapat melakukan perbandingan dengan responden yang sudah efisien secara teknis untuk memperbaiki penggunaan input-input produksinya. Petani responden yang memiliki nilai efisiensi sama dengan satu merupakan petani yang memiliki kinerja terbaik apabila dibandingkan dengan responden lainnya. Petani responden dengan kinerja terbaik ini akan dijadikan sebagai pembanding (benchmark) bagi responden lainnya.
Berdasarkan Lampiran 2, terlihat bahwa petani responden nomor satu (yang belum efisien secara teknis) dapat dibandingkan dengan tiga petani responden lainnya yang telah efisien secara teknis. Petani responden lainnya yang masih belum efisien secara teknis dan dapat dibandingkan dengan petani responden yang telah efisien secara teknis yaitu petani responden nomor 2, 6, 7, 9, 13, 16, 18, 21, 22, 23, 24, 26, 27, 28, 29, dan 31 (Lampiran 2).

Terkait dengan input slack, nilai yang tertera pada hasil perhitungan menunjukkan sejumlah input yang dapat dikurangi oleh petani responden untuk menghasilkan tingkat output yang sama. Di sisi lain, output slack merupakan sejumlah output yang dapat ditingkatkan tanpa perlu untuk menambah input. Namun pada penelitian ini digunakan asumsi model DEA berorientasi input. Oleh karena itu, perhitungan hanya difokuskan pada penilaian input slack.

Berdasarkan hasil yang diperoleh, terlihat bahwa rata-rata nilai input slack tersebar pada seluruh variabel input. Nilai rata-rata input slack untuk benih, pupuk urea, pupuk TSP, pupuk kandang, furadan, tenaga kerja dalam keluarga, dan 
Tabel 2. Nilai Input Berlebih (Input Slack) Rata-rata Petani Responden

\begin{tabular}{lccc}
\hline \multicolumn{1}{c}{ Variabel } & $\begin{array}{c}\text { Nilai Slack } \\
\text { Rata-Rata }\end{array}$ & $\begin{array}{c}\text { Persentase } \\
\text { Pengurangan }\end{array}$ & $\begin{array}{c}\text { Jumlah } \\
\text { Responden }\end{array}$ \\
\hline Benih & 0,179 & 9,50 & 11 \\
Pupuk Urea & 4,582 & 6,76 & 9 \\
Pupuk TSP & 6,262 & 14,82 & 12 \\
Pupuk Kandang & 136,918 & 16,92 & 14 \\
Furadan & 0,319 & 9,07 & 8 \\
Tenaga Kerja Dalam Keluarga & 1,079 & 9,48 & 9 \\
Tenaga Kerja Luar Keluarga & 3,145 & 14,55 & 13 \\
\hline
\end{tabular}

tenaga kerja luar keluarga masingmasing yaitu 0,$179 ; 4,582 ; 6,262 ; 6,846$; 0,$319 ; 1,079$; dan 3,145 . Nilai rata-rata input slack dari seluruh responden dapat dilihat pada Tabel 2.

Mengacu pada Tabel 2, secara umum, petani responden tidak efisien secara teknis karena masih terdapat penggunaan input yang berlebih untuk semua variabel yang digunakan. Berdasarkan hal tersebut, secara umum dari sisi input, usahatani jagung manis dari petani responden tidak efisien karena sebanyak 18 petani jagung manis di Desa Gunung Malang (sebesar 58,06 persen dari total responden) masih dapat mengurangi benih sebanyak 9,50 persen, pupuk urea sebanyak 6,76 persen, pupuk TSP sebanyak 14,82 persen, pupuk kandang sebanyak 16,92 persen, furadan sebanyak 9,07 persen, tenaga kerja dalam keluarga sebanyak 9,48 persen, dan tenaga kerja luar keluarga sebanyak 14,55 persen pada tingkat output yang sama. Pupuk kandang, pupuk TSP, dan tenaga kerja luar keluarga merupakan input produksi yang memiliki persentase pengurangan terbesar apabila dibanding-kan dengan input-input produksi lainnya. Oleh karena itu, petani dapat mengurangi penggunaan pupuk kandang sebanyak 136,918 kilogram (16,92 persen), pupuk TSP sebanyak 6,262 kilogram (14,82 persen), dan mengurangi penggunaan tenaga kerja luar keluarga sebanyak 3,145 HOK (14,55 persen) agar usahatani jagung manis yang dilakukan efisien secara teknis. Petani responden yang telah efisien apabila dilihat dari sisi input hanya sebanyak 41,94 persen dari total responden dengan pencapaian zero slack pada seluruh variabel.

Berdasarkan beberapa penjelasan di atas, dapat disimpulkan bahwa secara umum, usahatani jagung manis di Desa Gunung Malang pada musim tanam 2013-2014 tidak efisien secara teknis. Hasil ini sejalan dengan beberapa penelitian yang telah dilakukan oleh beberapa peneliti seperti Dao dan Lewis (2008), Iraizoz et al. (2003), Fogasari dan Latruffe (2007), dan Kirner et al. (2007) yang melakukan estimasi efisiensi usahatani pada berbagai komoditi pertanian di negara-negara berkembang. Estimasi efisiensi usahatani pada berbagai komoditi pertanian di beberapa negara maju juga menunjukkan hasil yang 
serupa, seperti pada penelitian Dhungana et al. (2004), Pugliese (2011), Abatania et al. (2012), serta Ogunniyi (2012). Berdasarkan beberapa penelitian tersebut, diperoleh hasil yang menunjukkan bahwa efisiensi teknis pada berbagai komoditi pertanian di beberapa negara diestimasikan relatif tidak efisien. Hanya dalam penelitian Yusuf dan Malomo (2007) diperoleh hasil yang menunjukkan bahwa mayoritas petani relatif sudah efisien secara teknis.

Pendekatan DEA banyak dilakukan untuk melihat efisiensi teknis dari beberapa tanaman pangan, seperti padi dan jagung, namun aplikasi pendekatan DEA untuk komoditas jagung manis masih jarang dilakukan, baik di Indonesia maupun di negara lain. Oleh karena itu untuk melihat perbandingan tingkat efisiensi teknis dari petani responden di lokasi penelitian, digunakan perbandingan dengan penelitian pada tanaman lainnya di beberapa negara.

Dhungana et al. (2004) dalam penelitiannya terhadap usahatani padi di Nepal menemukan bahwa petani secara umum tidak efisien secara teknis dalam penggunaan faktor-faktor produksi usahatani. Terdapat beberapa input yang penggunaannya berlebih dan terdapat pula beberapa input yang penggunaanya dinilai masih kurang apabila dibandingkan dengan usahatani referensi yang dianggap efisien menurut model. Kondisi tersebut tidak jauh berbeda dengan yang terjadi di Ethiopia. Seperti yang dikutip dari penelitian Pugliese (2011), mayoritas petani di Ethiopia relatif masih tidak efisien dalam melakukan kegiatan usahataninya. Hal ini juga serupa dengan yang diungkapkan oleh Ogunniyi (2012) dalam penelitiannya bahwa mayoritas petani jagung di Nigeria tidak efisien di dalam penggunaan faktor-faktor produksi usahatani.

Nilai mean pada efisiensi teknis usahatani padi di Nepal sebesar 76\% (Dhungana et al., 2004), sedangkan nilai mean pada efisiensi teknis usahatani padi di Thailand sebesar 74\% (Krasachat, 2004) dan nilai mean pada efisiensi teknis usahatani jagung di Nigeria sebesar 64,9\% (Ogunniyi, 2012). Pada penelitian ini, nilai mean yang diperoleh yaitu sebesar $87 \%$. Petani jagung manis di lokasi penelitian masih dapat meningkatkan efisiensi teknisnya sebesar $13 \%$. Berdasarkan hal tersebut terlihat bahwa usahatani jagung manis di Desa Gunung Malang memiliki nilai mean pada efisiensi teknis yang lebih tinggi apabila dibandingkan dengan petani padi di Nepal dan di Thailand, serta petani jagung di Nigeria. Hal ini menunjukkan bahwa kinerja usahatani jagung manis di lokasi penelitian cukup baik, meskipun masih terdapat beberapa input yang masih harus dikurangi penggunaannya.

\section{Faktor-Faktor yang Mempengaruhi Efisiensi Teknis}

Hasil pengolahan regresi Tobit menunjukkan bahwa pada taraf nyata $5 \%$, variabel yang memiliki pengaruh terhadap efisiensi teknis dari usahatani jagung manis di lokasi penelitian yaitu tingkat pendidikan formal (Tabel 3). Hasil yang diperoleh menunjukkan bahwa tingkat pendidikan formal memiliki pengaruh yang positif terhadap efisiensi teknis. Hal ini berarti bahwa 
Tabel 3. Hasil Regresi Tobit Petani Responden di Desa Gunung Malanga

\begin{tabular}{lrl}
\hline \multicolumn{1}{c}{ Variabel } & Koefisien & Pr $>|\boldsymbol{t}|$ \\
\hline Intersep & 0,858294 & 0,0041 \\
Usia (tahun) & 0,001999 & 0,6151 \\
Pendidikan Formal (tahun) & 0,038460 & $0,0110^{* * *}$ \\
Pengalaman Usahatani (tahun) & $-0,000701$ & 0,8878 \\
Jumlah Tanggungan (orang) & $-0,046953$ & $0,1184 *$ \\
Keanggotaan dalam Kelompok Tani & $-0,114079$ & $0,1762^{*}$ \\
(Dummy) & & \\
\hline
\end{tabular}

${ }^{\mathrm{a}}$ Keterangan: $* * *=$ Nyata pada taraf nyata $5 \% ; * *=$ Nyata pada taraf nyata $15 \% ; *$ = Nyata pada taraf nyata $20 \%$

peningkatan sebanyak satu tahun pada pendidikan formal petani akan meningkatkan efisiensi teknis petani sebesar 0,038460 .

Apabila dilihat pada taraf nyata $15 \%$, maka variabel lain yang memiliki pengaruh terhadap efisiensi teknis dari usahatani jagung manis di lokasi penelitian yaitu jumlah tanggungan di dalam rumah tangga petani. Koefisien pada variabel jumlah tanggungan di dalam rumah tangga menunjukkan nilai yang negatif, yang berarti bahwa semakin banyak jumlah tanggungan petani di dalam rumah tangga, maka efisiensi teknis dari petani tersebut akan berkurang sebesar 0,046953. Hasil yang diperoleh sejalan dengan hipotesis yang dikemukakan sebelumnya dan sejalan dengan hasil penelitian dari Rios dan Shively (2005) yang menunjukkan bahwa koefisien dari jumlah tanggungan petani di dalam rumah tangga menunjukkan secara signifikan hubungan yang negatif dengan efisiensi teknis. Hubungan negatif ini dapat terlihat ketika jumlah tanggungan petani di dalam rumah tangga petani cukup besar, maka jumlah ini secara tidak langsung akan memberatkan petani karena dengan semakin banyaknya jumlah tanggungan di dalam rumah tangga petani, maka akan berdampak pada tingginya pengeluaran untuk konsumsi di dalam rumah tangga tersebut. Tingginya pengeluaran untuk konsumsi rumah tangga akan membatasi petani dalam melakukan pembelian input-input produksi, sehingga dapat menyebabkan penggunaan input-input produksi menjadi tidak sesuai dengan penggunaan yang dianjurkan, terutama apabila harga input-input produksi tersebut cukup tinggi. Hal ini akan berdampak pada efisiensi dan produksi jagung manis dari petani tersebut. Hipotesis ini didukung dengan hasil perhitungan yang diperoleh, dimana petani responden yang memiliki jumlah tanggungan dalam rumah tangga sebanyak 7 orang memiliki nilai efisiensi teknis yang paling rendah apabila dibandingkan dengan responden lainnya, yaitu sebesar 0,405 (tidak efisien secara teknis).

Variabel lain yang memiliki pengaruh terhadap efisiensi teknis dari usahatani jagung manis di lokasi penelitian pada taraf nyata $20 \%$ yaitu 
keanggotaan petani dalam kelompoktani. Variabel ini juga memiliki koefisien yang bernilai negatif yaitu sebesar -0,114079, yang berarti bahwa apabila petani mengikuti keanggotaan dalam kelompok tani, maka efisiensi teknis petani akan lebih kecil 0,114079 dibandingkan dengan efisiensi teknis petani yang tidak mengikuti keanggotaan dalam kelompoktani. Hal ini bertentangan dengan hipotesis yang dikemukakan bahwa keanggotaan dalam kelompoktani diduga akan mampu meningkatkan efisiensi teknis dari usahatani yang dikelola.

Nilai negatif pada koefisien keanggotaan dalam kelompoktani menunjukkan bahwa kelompoktani di lokasi penelitian tidak memberikan pengaruh yang positif bagi petani di dalam melakukan kegiatan usahatani jagung manis. Hal ini salah satunya dapat dijelaskan dari alasan pembentukan kelompoktani tersebut. Pada awalnya, pembentukan kelompoktani di lokasi penelitian ditujukan untuk memperoleh bantuan dari program yang dilakukan oleh pemerintah. Selain itu, penyuluhan khusus terkait budidaya jagung manis hingga saat ini masih sangat jarang dilakukan akibat kurangnya tenaga penyuluh pertanian di Desa Gunung Malang. Intensitas pertemuan dari kelompoktani juga menjadi salah satu alasan yang menyebabkan rendahnya pengaruh kelompoktani bagi petani di dalam melakukan kegiatan usahatani jagung manis. Pada kurun waktu lima tahun terakhir, kelompoktani tersebut baru melakukan pertemuan khusus untuk berdiskusi terkait budidaya jagung manis sebanyak satu kali. Hal ini yang menyebabkan kelompoktani di lokasi penelitian tidak dapat memberikan pengaruh yang positif bagi petani di dalam melakukan kegiatan usahatani jagung manis.

Variabel lain yang digunakan dalam penelitian ini yaitu usia dan pengalaman usahatani. Namun kedua variabel ini merupakan variabel yang tidak memiliki pengaruh terhadap efisiensi teknis dari usahatani jagung manis di lokasi penelitian. Hal ini sejalan dengan penelitian dari Saptana (2012) yang menyatakan bahwa usia petani tidak dapat menjelaskan secara signifikan mengenai efisiensi teknis dari suatu usahatani. Namun untuk variabel pengalaman usahatani, hasil pada penelitian ini berbeda dengan penelitian yang dilakukan oleh Yusuf dan Malomo (2007). Pada penelitian tersebut, ditemukan adanya pengaruh yang signifikan dan positif dari variabel pengalaman usahatani di dalam mempengaruhi efisiensi teknis.

Perbedaan lokasi penelitian dapat menjadi salah satu penyebab adanya perbedaan pada hasil yang diperoleh. Petani yang efisien secara teknis di Desa Gunung Malang memiliki sebaran usia dan pengalaman yang cukup luas. Terkait pengalaman dalam berusahatani jagung manis, terlihat bahwa terdapat beberapa petani yang belum memiliki pengalaman cukup lama dalam melakukan usahatani jagung manis (2-6 tahun), namun petani tersebut telah efisien secara teknis. Begitu pula pada petani yang memiliki pengalaman cukup lama dalam melakukan usahatani jagung manis (25-30 tahun), petani tersebut juga telah efisien 
secara teknis. Hal ini yang membuat pengaruh dari variabel pengalaman tidak terlihat secara signifikan di dalam mempengaruhi efisiensi teknis usahatani jagung manis di lokasi penelitian. Selain itu, petani responden yang memiliki sedikit pengalaman berpeluang untuk dapat menyesuaikan dan belajar mengenai teknik budidaya jagung manis yang dilakukan oleh petani lainnya yang sudah berpengalaman. Petani responden di Desa Gunung Malang umumnya melakukan usahatani secara turuntemurun, sehingga petani tersebut dapat memperoleh pengetahuan tentang teknik budidaya dari orangtua atau anggota keluarga lainnya yang telah melakukan usahatani jagung manis. Beberapa hal tersebut yang membuat pengaruh dari variabel pengalaman tidak terlihat secara signifikan di dalam mempengaruhi efisiensi teknis usahatani jagung manis di lokasi penelitian.

Hal yang serupa juga dapat terlihat pada variabel usia petani. Petani responden yang telah efisien secara teknis tersebar pada beberapa kisaran usia, baik pada petani yang berusia muda maupun pada petani yang berusia tua. Hal ini yang menyebabkan tidak adanya pengaruh signifikan dari kedua variabel tersebut terhadap efisiensi teknis dari usahatani jagung manis di lokasi penelitian.

\section{KESIMPULAN DAN SARAN}

\section{Kesimpulan}

Berdasarkan hasil dan pembahasan yang telah diuraikan sebelumnya, maka kesimpulan yang diperoleh dari penelitian ini yaitu:
1. Sebagian besar petani menggunakan pola tanam padi-ubi jalar-jagung manis di dalam melakukan usahatani pada musim tanam 2013. Penggunaan input produksi rata-rata dari petani responden masih belum sesuai dengan penggunaan input yang dianjurkan, seperti pada penggunaan pupuk urea, pupuk TSP, pupuk kandang, dan furadan.

2. Hasil penelitian menunjukkan bahwa petani jagung manis di Desa Gunung Malang tidak efisien dalam penggunaan input-input produksi-nya. Upaya peningkatan efisiensi dalam usahatani jagung manis dapat dilakukan dengan cara menggunakan inputinput produksi sesuai dengan komposisi yang dianjurkan, yaitu salah satunya dengan cara mengurangi penggunaan input produksi yang berlebih seperti pupuk kandang, pupuk TSP, dan tenaga kerja luar keluarga.

3. Faktor-faktor yang mempengaruhi efisiensi teknis usahatani jagung manis di Desa Gunung Malang yaitu tingkat pendidikan formal, jumlah tanggungan di dalam rumah tangga petani, dan keanggotaan dalam kelompoktani. Sedangkan variabel usia dan pengalaman usahatani tidak mempengaruhi efisiensi teknis usahatani jagung manis di lokasi penelitian.

\section{Saran}

Berdasarkan penelitian yang telah dilakukan, saran yang dapat disampaikan antara lain: 
1. Untuk dapat melakukan usahatani jagung manis yang efisien secara teknis, petani responden di lokasi penelitian dapat mengurangi penggunaan input produksi yang masih berlebih. Pupuk kandang, pupuk TSP, dan tenaga kerja luar keluarga merupakan input produksi yang memiliki persentase pengurangan terbesar apabila dibandingkan dengan input-input produksi lainnya. Oleh karena itu, petani dapat mengurangi penggunaan pupuk kandang, pupuk TSP, dan tenaga kerja luar keluarga agar usahatani jagung manis yang dilakukan efisien secara teknis.

2. Diharapkan adanya penelitian lebih lanjut mengenai efisiensi alokatif dan efisiensi ekonomis dari usahatani jagung manis.

3. Tidak adanya pengaruh antara variabel usia dan pengalaman usahatani yang diperoleh dari hasil penelitian, maka pada penelitian selanjutnya dapat menggunakan variabel lainnya yang diduga dapat mempengaruhi efisiensi teknis dari usahatani jagung manis.

\section{DAFTAR PUSTAKA}

Abatania, LN, Hailu A, dan Mugera AW. 2012. Analysis of Farm Household Technical Efficiency in Northern Ghana using Bootstrap DEA. Paper presented at the $56^{\text {th }}$ Annual Conference of the Australian Agricultural and Resource Economics Society.
Amandasari, M. 2013. Pendapatan Usahatani Jagung Manis di Desa Gunung Malang Kecamatan Tenjolaya Kabupaten Bogor. [Skripsi]. Fakultas Ekonomi dan Manajemen. Institut Pertanian Bogor, Bogor.

[BPS]Badan Pusat Statistik Kabupaten Bogor. 2012. Produksi Jagung di Lima Provinsi Sentra Jagung Indonesia Tahun 2008-2011. BPS Kabupaten Bogor. Bogor.

Bakhsh, K, Ahmad B, dan Hassan S. 2006. Food Security Through Increasing Technical Efficiency. Asian Journal of Plant Sciences. 5(6): 970-976.

Dao, G dan Lewis P. 2008. Technical Efficiency of Annual Crop Farms in Northern Vietnam. Faculty of Business, Government and Law, University of Canberra.

Departemen Pertanian. 2009. Proyeksi Produksi Jagung Nasional 20102014 dan Proyeksi Kebutuhan Jagung Nasional 2010-2014. Bahan Rapim Bulan Agustus 2009. Departemen Pertanian.

Dhungana, BR, Nuthall PL, dan Nartea GV. 2004. Measuring the Economic Inefficiency of Nepalese Rice Farms Using Data Envelopment Analysis. The Australian Journal of Agricultural and Resource Economics. 48(2): 347-369.

[Dipertajabarprov] Dinas Pertanian Tanaman Pangan Provinsi Jawa Barat. 2012. Luas Tanam, Luas Panen, Produksi, dan Produktivitas Jagung di Kabupaten Bogor Tahun 2007-2011. Dinas Pertanian 
Tanaman Pangan Provinsi Jawa Barat.

Farrell, MJ. 1957. The Measurement of Productive Efficiency. Journal of the Royal Statistical Society. 253290.

Fogasari, J dan Latruffe L. 2007. Technical Efficiency and Technology in Eastern and Western Agriculture: A Comparison of Crop and Dairy Farms in Hungary and France. Paper Prepared for Persentation at the Joint IAAE-104th EAAE Seminar, Agricultural Economic and Transition: "What was Expected, What We Observed, The Lessons Learned." Corvinus University of Budapest (CUB), Budapest, Hungary.

Iraizoz, B, Rapun M, dan Zabaleta I. 2003. Assessing the Technical Efficiency of Horticultural Production in Navarra Spain. Agric. Sys. 78: 387-403.

Kementerian Pertanian. 2012. Laporan Kinerja Kementerian Pertanian Tahun 2011. Kementerian Pertanian. Jakarta.

Kirner, L, Ortner KM, dan Hambrusch J. 2007. Using Technical Efficiency to Classify Austrian Dairy Farms. Bodenkultur-Wien and Munchen-. 1(4): 15-24.

Krasachat, W. 2004. Technical Efficiencies of Rice Farms in Thailand: A Non-Parametric Approach. The Journal of American Academy of Business. 4(1): 64-69.

Maddala, GS. 1999. Limited Dependent Variable in Econometrics.
Cambridge University Press. Amerika Serikat.

Ogundari, K dan Ojo SO. 2007. An Examination of Technical, Economic and Allocative Efficiency of Small Farms: The Case Study of Cassava Farmers in Osun State of Nigeria. Bulgarian Journal of Agricultural Science, National Centre for Agrarian Sciences. 12: 185-195.

Ogunniyi, LT. 2012. Fertilizer Use Efficiency of Maize Producers in Ogun State of Nigeria. The Pacific Journal of Science and Technology. 13(2): 370-376.

Pugliese, A. 2011. Technical Efficiency of Smallholder Maize Producers in Ethiopia: The Case of Wolaita and Gamo Gofa Zones. American Journal of Agricultural Sciences. 2(3).

Saptana. 2012. Konsep Efisiensi Usahatani Pangan dan Implikasinya bagi Peningkatan Produktivitas. Forum Penelitian Agro Ekonomi. 30(2): 109 -128.

Sumaryanto, W dan Siregar M. 2003. Determinan Efisiensi Teknis Usahatani di Lahan Sawah Irigasi. Jurnal Agro Ekonomi. 21(1): 7296.

Tim Karya Tani Mandiri. 2010. Pedoman Bertanam Jagung. Nuansa Aulia. Bandung.

Yusuf, SA dan Malomo O. 2007. Technical Efficiency of Poultry Egg Production in Ogun State: A Data Envelopment Analysis (DEA) Approach. International Journal of Poultry Science. 6(9): 622-629. 
Lampiran 1. Constant Return to Scale Technical Efficiency Scores, Variable Return to Scale Technical Efficiency Scores, Scale Efficiency, dan Return to Scale dari setiap Petani Responden

\begin{tabular}{ccccc}
\hline DMU & CRSTE & VRSTE & SE & Keterangan \\
\hline 1 & 0,564 & 0,884 & 0,638 & IRS \\
2 & 0,890 & 0,954 & 0,933 & IRS \\
3 & 0,919 & 1,000 & 0,919 & IRS \\
4 & 1,000 & 1,000 & 1,000 & - \\
5 & 1,000 & 1,000 & 1,000 & - \\
6 & 0,596 & 0,647 & 0,920 & IRS \\
7 & 0,594 & 0,714 & 0,833 & IRS \\
8 & 1,000 & 1,000 & 1,000 & - \\
9 & 0,653 & 0,784 & 0,833 & IRS \\
10 & 1,000 & 1,000 & 1,000 & - \\
11 & 1,000 & 1,000 & 1,000 & - \\
12 & 1,000 & 1,000 & 1,000 & - \\
13 & 0,511 & 0,628 & 0,813 & IRS \\
14 & 1,000 & 1,000 & 1,000 & - \\
15 & 0,743 & 1,000 & 0,743 & IRS \\
16 & 0,539 & 0,583 & 0,924 & IRS \\
17 & 0,402 & 0,403 & 0,998 & IRS \\
18 & 0,521 & 0,618 & 0,842 & IRS \\
19 & 0,693 & 1,000 & 0,693 & DRS \\
20 & 1,000 & 1,000 & 1,000 & - \\
21 & 0,924 & 0,925 & 0,998 & IRS \\
22 & 0,890 & 0,996 & 0,893 & IRS \\
23 & 0,761 & 0,983 & 0,774 & IRS \\
24 & 0,665 & 0,693 & 0,959 & DRS \\
25 & 1,000 & 1,000 & 1,000 & - \\
26 & 0,830 & 0,858 & 0,968 & IRS \\
27 & 0,519 & 0,739 & 0,702 & DRS \\
28 & 0,524 & 0,764 & 0,686 & IRS \\
29 & 0,770 & 0,882 & 0,873 & IRS \\
30 & 1,000 & 1,000 & 1,000 & IRS \\
31 & 0,769 & 0,901 & 0,854 & \\
Mean & $\mathbf{0 , 7 8 3}$ & $\mathbf{0 , 8 7 0}$ & $\mathbf{0 , 8 9 7}$ & \\
\hline & & & & \\
\hline
\end{tabular}


Lampiran 2. Sebaran Perbandingan untuk Setiap Responden

\begin{tabular}{|c|c|c|c|c|c|c|}
\hline \multirow{2}{*}{ DMU } & \multicolumn{6}{|c|}{ Perbandingan dengan Responden ke- } \\
\hline & 1 & 2 & 3 & 4 & 5 & 6 \\
\hline 1 & 20 & 25 & & & & \\
\hline 2 & 30 & 20 & 15 & 5 & & \\
\hline 3 & 3 & & & & & \\
\hline 4 & 4 & & & & & \\
\hline 5 & 5 & & & & & \\
\hline 6 & 5 & 20 & 25 & 14 & & \\
\hline 7 & 12 & 14 & 25 & & & \\
\hline 8 & 8 & & & & & \\
\hline 9 & 5 & 15 & 30 & & & \\
\hline 10 & 10 & & & & & \\
\hline 11 & 11 & & & & & \\
\hline 12 & 12 & & & & & \\
\hline 13 & 25 & 14 & 20 & 5 & & \\
\hline 14 & 14 & & & & & \\
\hline 15 & 15 & & & & & \\
\hline 16 & 5 & 10 & 20 & 25 & & \\
\hline 17 & 12 & 5 & 30 & 25 & & \\
\hline 18 & 20 & 25 & 14 & 5 & & \\
\hline 19 & 19 & & & & & \\
\hline 20 & 20 & & & & & \\
\hline 21 & 5 & 12 & 11 & 8 & 30 & 25 \\
\hline 22 & 20 & 25 & 10 & & & \\
\hline 23 & 15 & 20 & 30 & 25 & & \\
\hline 24 & 25 & 12 & 5 & & & \\
\hline 25 & 25 & & & & & \\
\hline 26 & 20 & 5 & & & & \\
\hline 27 & 19 & 14 & 5 & & & \\
\hline 28 & 15 & 5 & 30 & & & \\
\hline 29 & 5 & 8 & 15 & 30 & & \\
\hline 30 & 30 & & & & & \\
\hline 31 & 5 & 25 & 15 & 20 & & \\
\hline
\end{tabular}


Melissa Amandasari, Rita Nurmalina dan Amzul Rifin 